\title{
EVALUATION OF SKILLS DEVELOPMENT METHODS: INTERCULTURAL STUDY OF STUDENTS' ATTITUDES
}

\author{
Vilmantė Kumpikaite ${ }^{1}$, Antonio Mihi Ramírez ${ }^{2}$, Humberto Nuno Rito Ribeiro ${ }^{3}$ \\ ${ }^{I}$ Kaunas University of Technology, Lithuania, vilmante.kumpikaite@ktu.lt \\ ${ }^{2}$ University of Granada, Spain, amihi@ugr.es \\ ${ }^{3}$ Instituto Politécnico de Bragança,Portugal,humberto@alumni.dmu.ac.uk \\ crossref http://dx.doi.org/10.5755/j01.em.17.3.2142
}

\begin{abstract}
Intensive global competition, higher customer expectations and greater focus on quality have resulted in much greater requirements placed upon employees today than decades ago. The challenge has been to internalize a new type of organizational behavior in order to operate successfully under unfamiliar conditions. Professors have to choose the best skills developing methods for students. This paper introduces students' skills development methods' evaluation. Authors look for those evaluation's differences in two older European Union countries Spain and Portugal, one of the newest European Union country's Lithuania, candidate to European Union, situated in Europe and Asia - Turkey, and then Iran - the Middle East. The empirical research is based on theoretical background and presets investigation of student's skills, developing factors and differences according to students' nationality.

Keywords: skills; skills' development methods; learning methods; students.

JEL Classification: M12, A22, I20, O15.
\end{abstract}

\section{Introduction}

Questions of competency and employees' skills development, were quite widely researched by foreign and Lithuanian authors: Carmichael \& Routledge (1993), Parry (1998), Hagan, Konopaske, Bernardin \& Tyler (2006), Kazlauskaite \& Buciuniene (2008), Zakarevicius \& Zuperkiene (2008), Kumpikaite (2009), Kumpikaite \& Ciarniene (2008a, b), Savaneviciene, Stukaite \& Silingiene (2008), and others. However, developing countries are still preoccupied with conventional management techniques and are left with ineffective management (Jones \& Woodcock, 1985). This problem is still relevant in many countries. It is crucial, therefore, to identify the skills and knowledge which contribute to the development and effectiveness of managers in these countries so they can share the same benefits with their counterparts in developed nations. Authors of this paper selected for this study Lithuania and Turkey as still developing countries. Lithuania is Eastern European country, one of the newest countries of European Union and under big economic crises" influence. Turkey is situated in two continents: Europe and Asia and is a candidate to EU.

The purpose of this paper is to analyze skills typology and them developing method, and to present results of intercultural empirical study of university students' skills development evaluation.

Research methods of this paper are the analysis of scientific literature, empirical research (structured questionnaire survey) and statistical data analysis, using SPSS and Excel programs. Looking at students' skills evaluation, the research design is based on Katz (1974), Whetten \& Cameron (2002), Analoui (1993) and Peterson \& Van Fleet (2004) typologies. Speaking about students training methods, methodology was developed analyzing scientific literature and based on Noe (2003), Mankin (2009) theoretical frameworks and previous empirical researches provided by Kumpikaite \& Sakalas (2008) and Kumpikaite \& Alas (2009).

This paper is organized as following. Firstly, theoretical part, analyzing characteristics of skills' types and their development methods is given; secondly, empirical part, presenting results of research of students' skills evaluation and them developing methods in Lithuania, Spain, Iran, Turkey and Portugal is provided and finally, conclusions and discussion are proposed.

\section{Theoretical background}

\section{Skills typology.}

According to Business dictionary skills are described as ability and capacity acquired through deliberate, systematic, and sustained effort to smoothly and adaptively carryout complex activities or job functions involving ideas (cognitive skills), things (technical skills), and/or people (interpersonal skills).

As Labbaf, Analoui \& Cusworth (1996) state, corresponding with the overwhelming emphasis on the skill approach to management development and along with its increased acceptability, several taxonomies of managerial skills have been put forward. They mention that the most notable being typologies of Katz (1974), Boyatzis (1982), and Whetten \& Cameron (2002). 
There are five skill sets that cover the dimensions of competency and these are defined in the Australian vocational training system. From Resources for the Training Package, they are:

- Task Skills - the requirement to perform individual tasks to an acceptable level of skill (recall information or terms, application of process.)

- Task Management Skills - the requirement to manage a number of different tasks within the job (priority setting, sequencing of tasks, tips to make job easier).

- Contingency Management Skills - the requirement to respond to irregularities and react appropriately when things go wrong (what do you do if, who to contact, why is it important).

- Job/Role Environment Skills - the requirement to deal with the responsibilities and expectations of the work environment, including interacting appropriately with others in the workplace (duty of care, obligations, safety requirements).

- Ability to Transfer Skills - the requirement to transfer knowledge, skills and attitudes to new situations.

Peterson \& Van Fleet (2004) summarized the 23 textbooks, some of which are new editions of the original 15 textbooks they analyzed, identified a total of ten core skills. These authors (Peterson \& Van Fleet, 2004) provide a list of the managerial skills identified in the textbooks along with a definition for each skill:

- Technical - ability to use methods, procedures, processes, tools, techniques, and specialized knowledge to perform specific tasks;

- Analytic - ability to identify key variables, see how they are interrelated, and decide which ones should receive the most attention;

- Decision making - ability to choose effective solutions from among alternatives

- Human - ability to work cooperatively with others, to communicate effectively, to motivate and train others, to resolve conflicts, and to be a team player;

- Communication - ability to send and receive information, thoughts, and feelings, which create common understanding and meaning;

- Interpersonal - ability to develop and maintain a trusting and open relationship with superiors, subordinates and peers to facilitate the free exchange of information and provide a productive work setting;

- Conceptual - ability to see the organization as a whole and to solve problems from a systemic point of view;

- Diagnostic - ability to determine the probable cause of a problem from examining the symptoms which are observed by the manager;

- Flexible - ability to deal with ambiguous and complex situations and rapidly changing demands;

- Administrative - ability to follow policies and procedures, process paper work in an orderly manner, and manage expenditures within the limits set by budgets.

Summarizing all reviewed authors skills' typologies Table 1 is given.

Table 1. Skills Typologies according to Different Sources

\begin{tabular}{|c|c|c|c|c|c|c|}
\hline & Katz (1974) & $\begin{array}{l}\text { Analoui } \\
\text { (1993) }\end{array}$ & $\begin{array}{c}\text { Whetten and } \\
\text { Cameron } \\
(2002) \\
\end{array}$ & $\begin{array}{l}\text { Peterson \& Van } \\
\text { Fleet }(2004)\end{array}$ & $\begin{array}{c}\text { Australian } \\
\text { vocational } \\
\text { training system } \\
\end{array}$ & $\begin{array}{c}\text { Cameron and } \\
\text { Tschirhart } \\
(\mathbf{1 9 8 8})\end{array}$ \\
\hline$\frac{a}{\vec{z}}$ & $\begin{array}{l}\text { Technical; } \\
\text { Human; } \\
\text { Conceptual }\end{array}$ & $\begin{array}{l}\text { Task-related; } \\
\text { People- } \\
\text { related; } \\
\text { Analytical and } \\
\text { self-related } \\
\text { skills }\end{array}$ & $\begin{array}{l}\text { Personal; } \\
\text { Interpersonal; } \\
\text { Group }\end{array}$ & $\begin{array}{l}\text { Technical; } \\
\text { Analytic; } \\
\text { Decision making; } \\
\text { Human; } \\
\text { Communication; } \\
\text { Interpersonal; } \\
\text { Conceptual; } \\
\text { Diagnostic; } \\
\text { Flexible; } \\
\text { Administrative }\end{array}$ & $\begin{array}{l}\text { Task Skills; } \\
\text { Task } \\
\text { Management; } \\
\text { Contingency; } \\
\text { Management; } \\
\text { Job/Role } \\
\text { Environment; } \\
\text { Ability } \\
\text { Transfer }\end{array}$ & $\begin{array}{l}\text { Human Relations; } \\
\text { Competitiveness } \\
\text { and control; } \\
\text { Innovation; } \\
\text { Rational thinking }\end{array}$ \\
\hline
\end{tabular}

\section{Skills development.}

Speaking about skills development we could speak about training, teaching and learning. Teaching methods are divided in to traditional and e-learning (modern) methods. They include different techniques. However in this paper we pay the biggest attention to development from individual positions, how students 
evaluate development methods when they learn. Therefore we speak about self-development and learning methods.

These methods could be developed in accordance of their techniques as traditional and modern computer based methods or number of people involved in learning process. We selected the second typology to reach goals of our paper. Therefore based on Noe (2003), Mankin (2009) Kumpikaite \& Sakalas (2007, 2008) given and analyzed methods, we could provide following skills development, based on learning methods', model (see Figure 1).

Individual or self-learning methods are such, which allow trainees to learn alone, independent from others. Traditional methods, such as Reading special literature and modern as Internet browsing or Interactive video watching are involved to these methods. One-to-one learning methods are such methods when a trainee is involved to the learning process together with other person, which could be a teacher or other trainee too. Group learning methods are such methods when several participants are involved in to learning process. Group methods are described as the best developing methods (Kumpikaite \& Ciarniene, 2008 a,b). Therefore we can see that there are a lot traditional (as Lectures, Groups projects, Discussions and others) as well as modern (E-learning or Learning networks) group learning methods. Certainly not all methods given in Figure 1 are very popular and well known.

\begin{tabular}{|c|c|c|}
\hline \multicolumn{3}{|c|}{ Skills development methods } \\
\hline ב & 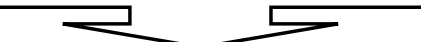 & $\Longrightarrow$ \\
\hline Individual learning & One-to-one learning & Group learning \\
\hline$\Rightarrow \quad 5$ & $\Longrightarrow$ & 马 5 \\
\hline Assignments & Coaching & \multirow{15}{*}{$\begin{array}{l}\text { Action learning Set } \\
\text { Assignment } \\
\text { Brainstorming } \\
\text { Business game } \\
\text { Case study } \\
\text { Discussion } \\
\text { E-learning } \\
\text { Field trip } \\
\text { Group exercise: inter- } \\
\text { personal skills } \\
\text { Group project } \\
\text { In-tray exercise } \\
\text { Learning networks } \\
\text { Involvement into other work } \\
\text { areas } \\
\text { Lecture }\end{array}$} \\
\hline Internet browsing & Counselling & \\
\hline Interactive video & Demonstration & \\
\hline Reading special literature & Exercises & \\
\hline & Considering of received task & \\
\hline & with the supervisor & \\
\hline & & \\
\hline & & \\
\hline & & \\
\hline & & \\
\hline & & \\
\hline & & \\
\hline & & \\
\hline & & \\
\hline & & \\
\hline
\end{tabular}

Figure 1. Skills development methods

Based on earlier described managerial skills and learning methods research methodology was prepared and presented in next section.

\section{Empirical research and its results}

\section{Introduction of study and sample.}

A survey was carried out by distributing questionnaires, which was designed and tested for this purpose earlier (Kumpikaite (2009), Alas \& Kumpikaite (2009)). Original questionnaire was prepared in Lithuanian. Questionnaires were prepared in respondents' native languages for this study. Therefore, original research instrument was translated in to English later, using double translation method for checking, and given to Turkey, Spain and Portugal and Iran where it was translated in to these languages and set out for survey. The questionnaires were given throw Internet in Lithuania, Turkey and Spain, and printed questionnaires were distributed in Portugal and Iran.

1. The main questions formulated in this study were:

2. What skills are evaluated the worst?

3. What skills' evaluation methods do students evaluate the best and the worst?

4. What are differences among students' answers according to countries?

5. The study was provided in 2011. General information about respondents is given in Table 2 . 
Table 2. Information about respondents according their country and gender

\begin{tabular}{|c|c|c|c|c|c|c|c|c|}
\hline & & & \multicolumn{5}{|c|}{ Country } & \multirow[b]{2}{*}{ Total } \\
\hline & & & Lithuania & Turkey & Iran & Spain & Portugal & \\
\hline \multirow[t]{8}{*}{ Gender } & \multirow[t]{4}{*}{ Male } & Count & 65 & 91 & 103 & 44 & 23 & 326 \\
\hline & & $\%$ within Sex & $19,9 \%$ & $27,9 \%$ & $31,6 \%$ & $13,5 \%$ & $7,1 \%$ & $100,0 \%$ \\
\hline & & $\%$ within Country & $32,0 \%$ & $57,2 \%$ & $53,4 \%$ & $34,6 \%$ & $65,7 \%$ & $45,5 \%$ \\
\hline & & $\%$ of Total & $9,1 \%$ & $12,7 \%$ & $14,4 \%$ & $6,1 \%$ & $3,2 \%$ & $45,5 \%$ \\
\hline & \multirow[t]{4}{*}{ Female } & Count & 138 & 68 & 90 & 83 & 12 & 391 \\
\hline & & $\%$ within Sex & $35,3 \%$ & $17,4 \%$ & $23,0 \%$ & $21,2 \%$ & $3,1 \%$ & $100,0 \%$ \\
\hline & & $\%$ within Country & $68,0 \%$ & $42,8 \%$ & $46,6 \%$ & $65,4 \%$ & $34,3 \%$ & $54,5 \%$ \\
\hline & & $\%$ of Total & $19,2 \%$ & $9,5 \%$ & $12,6 \%$ & $11,6 \%$ & $1,7 \%$ & $54,5 \%$ \\
\hline \multirow{2}{*}{\multicolumn{2}{|c|}{ Total }} & Count & 203 & 159 & 193 & 127 & 35 & 717 \\
\hline & & $\%$ of Total & $28,3 \%$ & $22,2 \%$ & $26,9 \%$ & $17,7 \%$ & $4,9 \%$ & $100,0 \%$ \\
\hline
\end{tabular}

\section{Measures.}

Synthesizing the works of Katz (1974), Whetten \& Cameron (2002), Analoui (1993) and Peterson \& Van Fleet (2004) (see Table 1), basic 16 management skills were selected and changed to form the wording of the questions for students' skills evaluation survey. These skills were divided in to four groups: (1) Personal skills (4 items); (2) Technical skills (3 items); (3) Human or interpersonal skills (6 items); (4) Conceptual skills (3 items).

Trying to find out the most students skills developing methods (see Figure 1) the most popular and known for students' traditional and modern learning methods were selected: (1) Individual learning (3 items); (2) One-to-one learning (3 items); (3) Group learning (6 items).

The scale for evaluations was divided in to 4 levels: 0 - weak, 1 - average, 2 - good and 3 - excellent. Means and Spearman's correlation were used for analysis in this paper.

Results.

First of all evaluation of students' skills is presented in Table 3.

Table 3. Evaluation of skills by countries

\begin{tabular}{|c|c|c|c|c|c|c|c|c|}
\hline & & Lithuania & Turkey & Iran & Spain & Portugal & Total & Average \\
\hline \multirow{3}{*}{ 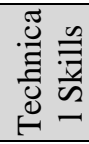 } & Subject knowledge & 2,04 & 1,86 & 1,96 & 1,67 & 2,75 & 1,95 & \multirow[b]{3}{*}{1,88} \\
\hline & Specialty experience & 1,38 & 1,60 & 1,64 & 0,77 & 2,12 & 1,85 & \\
\hline & Application experience & 2,03 & 2,16 & 2,17 & 0,59 & 2,50 & 1,85 & \\
\hline \multirow{6}{*}{ 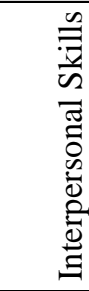 } & Self-presentation & 2,17 & 2,39 & 2,38 & 0,78 & 2,16 & 2,02 & \multirow[b]{6}{*}{2,16} \\
\hline & Ability to contact & 2,32 & 2,42 & 2,42 & 1,88 & 2,36 & 2,29 & \\
\hline & Ability to show own opinion & 2,38 & 2,37 & 2,36 & 1,52 & 2,29 & 2,17 & \\
\hline & Communicability & 2,28 & 2,33 & 2,34 & 0,85 & 2,29 & 2,01 & \\
\hline & Ability to work in team & 2,36 & 2,43 & 2,39 & 2,12 & 2,43 & 2,34 & \\
\hline & Self-reliance & 2,15 & 2,35 & 2,36 & 1,40 & 2,41 & 2,12 & \\
\hline \multirow{3}{*}{ 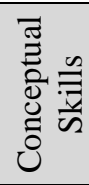 } & Ability to solve problems & 2,25 & 2,37 & 2,33 & 0,91 & 2,31 & 2,05 & \multirow[b]{3}{*}{2,06} \\
\hline & Analytic thinking & 2,14 & 1,97 & 2,02 & 1,77 & 2,12 & 2,00 & \\
\hline & $\begin{array}{l}\text { Goal understanding, ability to plan, } \\
\text { analyze results }\end{array}$ & 2,31 & 2,10 & 2,17 & 1,83 & 2,03 & 2,12 & \\
\hline \multirow{4}{*}{ 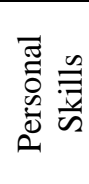 } & Responsibility sense & 1,95 & 2,56 & 2,46 & 1,02 & 2,63 & 2,07 & \multirow[b]{4}{*}{2,08} \\
\hline & Creativeness & 2,23 & 2,25 & 2,29 & 1,27 & 2,23 & 2,07 & \\
\hline & Activity & 2,13 & 2,33 & 2,32 & 1,18 & 2,32 & 2,05 & \\
\hline & Criticism tolerance & 2,64 & 2,02 & 2,16 & 1,50 & 1,94 & 2,12 & \\
\hline
\end{tabular}

Looking at results of skills evaluation we can see that technical skills, especially specialty experience is evaluated the worst. However Portuguese evaluated their criticism tolerance the worst, when Lithuanians evaluated it the best at the same time. Very low specialty experience's measure is not surprising as students lack it during their studies as well as application experience. Therefore results show the need of developing technical skills the most. 
Speaking about students' skills development methods next analysis was made. According to Table 4 we can see that Lithuanians, Turks and Iranians are most developed by one-to-one learning methods, Spanish and Portuguese prefer group learning at the same time. However these methods are at least developing for Turks and Iranians.

The highest evaluation of common results are for one-to-one learning methods (Mean=2.22), individual learning is on the second place (Mean=2.11) and group learning - on the third place (Mean=2.08).

Table 4. Means of skills development methods by countries

\begin{tabular}{|l|r|r|r|r|r|r|}
\hline & Lithuania & \multicolumn{1}{|c|}{ Turkey } & \multicolumn{1}{c|}{ Iran } & \multicolumn{1}{c|}{ Spain } & Portugal & \multicolumn{1}{c|}{ Total } \\
\hline Individual learning & 2,01 & 2,31 & 2,25 & 1,28 & 1,60 & 2.11 \\
\hline One-to-one learning & 2,30 & 2,29 & 2,30 & 1,39 & 1,48 & 2.22 \\
\hline Group learning & 2,18 & 2,02 & 2,04 & 2,19 & 1,63 & 2.08 \\
\hline
\end{tabular}

Figure 2 gives evaluation of every method by country and we can see very different results among them. Team work gets one of the highest evaluation and the lowest difference among countries' answers. Results showed that distance learning was selected as developing at least. However we could think that not all students used this method of learning before therefore cannot know its effort.

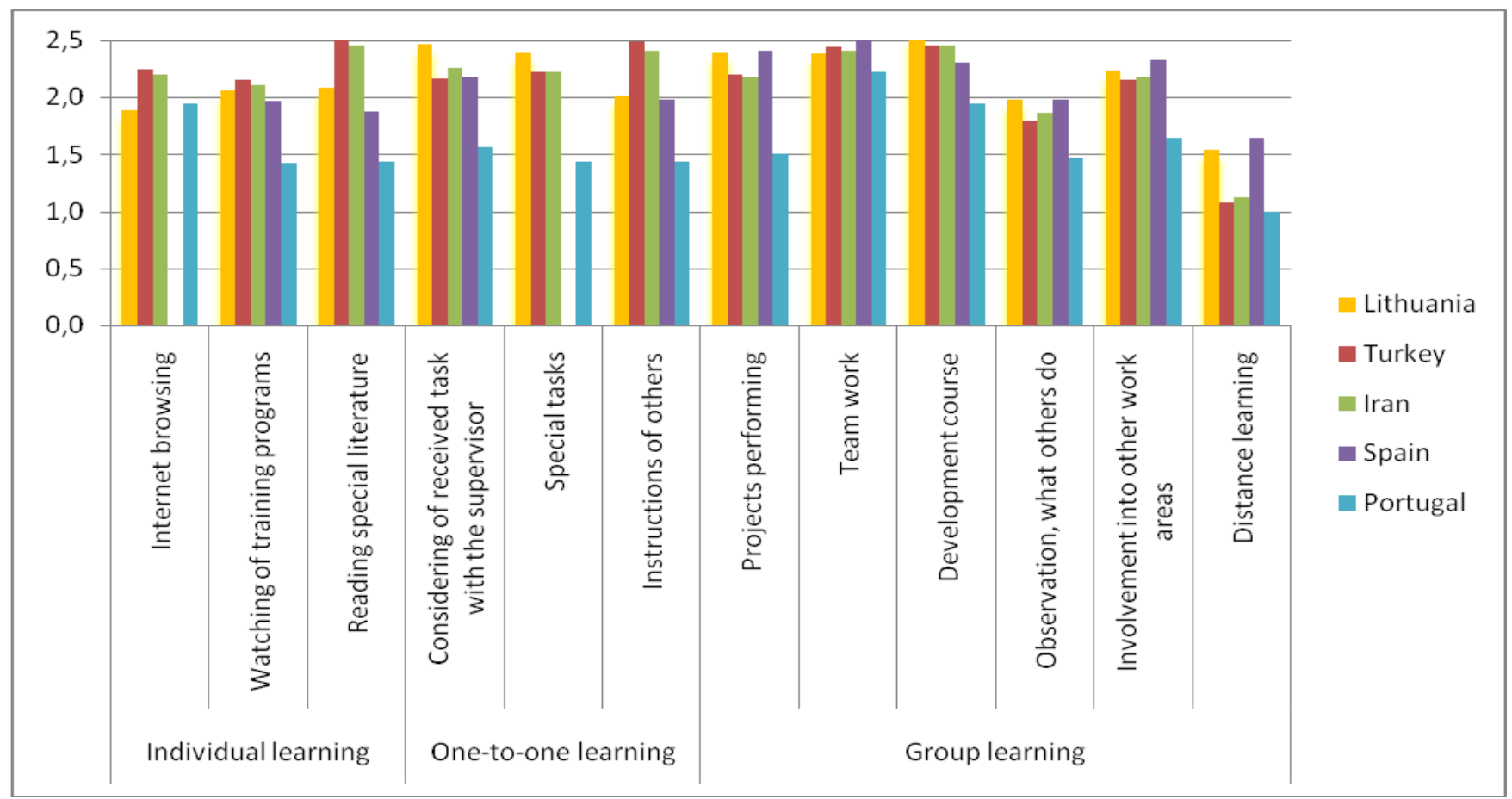

Figure 2. Evaluation of skills development methods

Table 5 presents comparison analysis of pair countries where statistical significant differences were found. Portuguese data for statistical comparison analysis was not used, as sample is too small. Moreover, no statistical difference among development methods between Turkey and Iran was found so no data about this is given in Table 5. Spanish did not evaluate their Internet browsing and Special tasks delivering, therefore we cannot compare them according these 2 methods.

According to comparison analysis (see Table 5), Lithuanians are more developed by distance training and considering of received task with supervisor Instructions of others and worse by reading of educational literature, Instruction of others and Internet browsing than Turks.

Lithuanians are more developed by project performing, special tasks, distance training and considering tasks with supervisor and worse instruction of others, reading literature and Internet browsing comparing with Iran. 
Lithuanians evaluated their skills development by reading special literature, considering of received task with supervisor and development courses better than Spanish. No Spanish evaluation was better than Lithuanians.

Table 5. Comparison analysis of learning methods evaluation between countries

\begin{tabular}{|c|c|c|c|c|c|c|}
\hline Methods & & LT-TR & LT-IR & LT-SP & TR-SP & IR-SP \\
\hline \multirow{3}{*}{ 胥 } & Internet browsing & + & + & $\mathrm{X}$ & $\mathrm{X}$ & $\mathrm{X}$ \\
\hline & Watching of training programs & No difference & No difference & No difference & - & - \\
\hline & Reading special literature & + & + & - & - & No difference \\
\hline \multirow{3}{*}{ 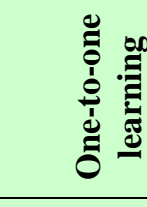 } & $\begin{array}{l}\text { Considering of received task } \\
\text { with the supervisor }\end{array}$ & - & - & - & No difference & - \\
\hline & Special tasks & No difference & - & $\mathrm{X}$ & $\mathrm{X}$ & $\mathrm{X}$ \\
\hline & Instructions of others & + & + & No difference & - & - \\
\hline \multirow{6}{*}{ 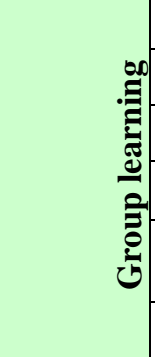 } & Projects performing & No difference & - & No difference & No difference & + \\
\hline & Team work & No difference & No difference & No difference & No difference & No difference \\
\hline & Development course & No difference & No difference & - & - & - \\
\hline & Observation, what others do & No difference & No difference & No difference & No difference & No difference \\
\hline & $\begin{array}{l}\text { Involvement into other work } \\
\text { areas }\end{array}$ & No difference & No difference & No difference & No difference & No difference \\
\hline & Distance learning & - & - & No difference & + & + \\
\hline
\end{tabular}

Spanish are more developed by distance training and worse by watching training programs, instructions of others, development courses and Reading literature in comparison with Turks.

Spanish are more developed by distance training and project performing and worse by watching training programs, instructions of others, development courses, reading literature and considering tasks with supervisor measuring them with Iranians.

\section{Conclusion and discussion}

Results of our empirical research showed that learning methods differ on respondents and on their gender a bit. Females are developed by special tasks, and distance training and less by instructions of others than males. Spanish and Portuguese prefer group learning the most. However these methods are at least developing for Turks and Iranians. They prefer one-to-one learning methods, as well as Lithuanians. It could be related with respondents' culture. Even so the reasons of differences in preferences of learning methods should be analyze further in other studies, which was not done in this one. Study revealed that students who can show their own opinion better prefer Project performing more than students who's Ability to show their own opinion is not developed so well. Moreover, this research showed that respondents who's Ability to show own opinion was evaluated higher evaluated all their skills especially Communicability and Self reliance higher too. It is not surprising as these skills are very connected and all belong for Interpersonal skills group.

Thinking that the world is influenced by globalization so much our explored students will be involved to work in international groups and organizations. Therefore their skills should be developed in accordance with these requirements.

Looking at differences among respondents' skills and work experiences it was found that students having bigger work experiences evaluated better just one skill. And this skill is Specialty experience. At the same time, respondents having longer work experience like Reading special literature, Considering of received task with the supervisor, Developing courses and Watching training problems less that other students and prefer Distance training as the most developing method.

All students lack technical skills the most, therefore professors should pay their attention to this development. All received results could be useful for professors teaching students and for every person identifying their week sides and necessity to develop skills. One group of students prefers individual traditional or modern, others like group methods, third ones - one-to one methods. Therefore professors 
should use more various teaching methods as students are different and every person accepts the same methods different. However it should be noted that more detail research is needed to look at students' used learning methods and them developing style. And it could be depicted as research limitation. As study conditions are various in different classes and different countries and students face with different teachers and methods, it is really quite complicated to highlight the most developing factors and differences among respondents' groups.

\section{References}

1. Analoui, F. (1993). Skills of management. In J.W.Cusworth \& T.F. Franks (Eds), Managing Projects in Developing Countries. Longman.

2. Australian vocational training system. Resources for the Training Package. Retrieved from http://www.resourcegenerator.gov.au/loadpage.asp?page=TPAG.htm

3. Boyatzis, R. (1982). The Competent Manager. New York, NY: Wiley- Interscience.

4. Business Dictionary. Retrieved from http://www.businessdictionary.com/article/

5. Carmichael, J.L. \& Routledge C. W. (1993). Managing Skills, Development Process. Industrial and Commercial Training, 25(2), 18-22. Retrieved June 15, 2010, from the Emerald Group Publishing Limited database.

6. Hagan, C. M., Konopaske, R., Bernardin, H.J. \& Tyler, C.L. (2006). Predicting assessment centre Performance with 360-degree, top-down, and customer-based competency assessments. Human Resource Management, 45(3), 357-390.

7. Katz, R.L. (1974). Skills of an effective administrator. Harvard Business Review, 52, 90-102.

8. Kazlauskaite, R. \& Buciuniene, I. (2009). The Role of Human Resources and Their Management in the Establishment of Sustainable Competitive Advantage. Inzinerine ekonomika - Engineering Economics. 15(60), 7884 .

9. Kumpikaite, V. (2009). Students as future performers: comparable analysis at Kaunas University of Technology, Lithuania. In Congress Proceedings, International 7th Knowledge, Economy \& Management (1117-1128). Istanbul University.

10. Kumpikaite, V., \& Alas, R. (2009). Students' Attitudes to Work and Studies: Practical Case. Economics and Management $=$ Ekonomika ir vadyba: 14 (582-588). Kaunas: Technologija.

11. Kumpikaite, V. \& Ciarniene, R. (2008a). New training technologies and their use in training and development activities: Survey evidence from Lithuania. Journal of Business Economics and Management, 9(2), 155-159.

12. Kumpikaite, V. \& Ciarniene, R. (2008b). New training technologies developing human resource. Economics and Management $=$ Ekonomika ir vadyba: No.13 (pp. 368-373). Kaunas: Technologija.

13. Kumpikaite, V. \& Sakalas, A. (2008). Human resource development system evaluation in companies in the furniture trade in Lithuania. EBS Review: Organizational Change and Development in Transitional Countries, $1(24), 63-82$

14. Kumpikaite, V. \& Sakalas, A. (2007). Human resource development in innovation process in the age of globalization (Lithuanian study). The 5th International Symposium on Management Technology ISMOT'07: Managing total innovation and open innovation in the 21st Century (pp. 408-412). Zhejiang University Press.

15. Labbaf, H., Analoui, F. \& Cusworth, J.W. (1996). Senior managers' effectiveness: the case of the steel industry in Iran. Journal of Management Development, 15(9), 47-63. Retrieved June 15, 2010, from the Emerald Group Publishing Limited database

16. Mankin, D. (2009). Human resource development. Oxford university press.

17. Noe, R.A. (2005). Employee Training and Development (Third Edition). The McGraw Hill.

18. Parry, S. B. (1998). Just what is a competency? (And why should you care?). Training, 35(6), 58-64.

19. Peterson, T.O. \& Van Fleet, D.D. (2004). The ongoing legacy of R.L. Katz: An updated typology of management skills. Management Decision, 42, 1297-1308. doi: 10.1108/00251740410568980, Retrieved June 15, 2010, from the Emerald Group Publishing Limited database

20. Savaneviciene, A, Stukaite, D. \& Silingiene, V. (2008). Development of strategic individual competences. Inzinerine ekonomika - Engineering Economics, 3(58), 81-88.

21. Zakarevicius, P. \& Zuperkiene, E. (2008). Improving the Development of Managers' Personal and Professional Skills. Inzinerine ekonomika - Engineering Economics, 5(60), 104-113.

22. Whetten, D.A. \& Cameron, K.S. (2002). Developing Management Skills. Englewood Cliffs, NJ: Prentice-Hall. 